\title{
企業城下町における産学官連携と主体間関係の変容 山口県宇部市を事例として——
}

\author{
外柜保大介（東京大学大学院生)
}

\begin{abstract}
本稿は, 宇部興産の企業城下町である山口県宇部市を事例として, 産学官連携による主体間関係の変容に 関する実態解明を通じて, 産学官連携が産業集積の質的变化に果たしつつある役割を考察する。従来の主体 間関係は，宇部興産とその下請企業から成る垂直的な構造であった。一方，1950 年代の産学官連携による 公害の克服や 1980 年代のテクノポリスの指定など, 大学々企業・自治体との関係も構築され, 今日の産学 官連携の基盤となった。1990 年代以降，産学官連携の進展により，宇部興産に加えて山口大学が主体間関 係の中核になっている，宇部興産は，山口大学と包括的連携を結び，製品開発の高付加価值化を進めている. 一方, 中小企業は, 技術等を獲得し, 取引相手や共同研究相手を拡げている. 特に宇部興産の下請企業に之 って, 産学官連携は, 脱下請化を促進させる可能性がある。このように産学官連携は, 産業集積のロックイ ンを解放し, それを水平的構造に転換させるという重要な意味がある。

キーワード：企業城下町, 産学官連携, 主体間関係, 山口県宇部市
\end{abstract}

\section{I 序 論}

1990 年代以降, 経済のグローバル化が進展する 中，日本の製造業では，競合する中国などとの差別 化を図るために，高付加価值な製品の開発・製造が 求められており，イノベーションや知識創造に高い 関心が集まっている，このような状況の下，イノベ ーションの源泉としての大学と産業界とを連携させ る産学連携が推進されている.1995 年の科学技術 基本法の制定を皮切りに，1998 年には大学等技術 移転促進法, 2000 年には産業技術力強化法 1）が制 定されるなど，産学連携の促進に向けた環境整備が 進んできた 2)。さらに最近では，産学連携に「官」 が積極的な関与をする「産学官連携」が推進されて いる.

産学官連携の代表的な事例がクラスター戦略であ る.クラスター戦略は，ポーター $(1992 ， 1999 ） の$ 議論をもとに, 各国で進められている。日本でも,

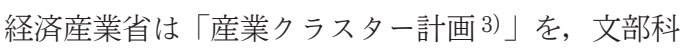

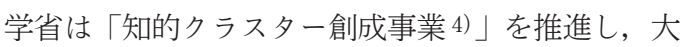
学が持つシーズを活用したクラスターの形成を目指
している（石倉ほか 2003）。

このような政策動向の一方で，1990 年代以降， 産業集積に関して多数の理論的・実証的研究が蓄積 されてきた.

産業集積に関する従来の研究は, 集積内の下請構 造（中央大学経済研究所 1976; 渡辺 1990）や仲間 取引（渡辺 1979）に関する分析など, 主として企 業間関係等の経済的取引関係を軸とした分析に重点 が置かれてきた。集積内のネットワーク形成や広域 連携といった協調的な企業間関係に対しても分析さ れている（山川 1995; 鎌倉 2002; 加藤 2003; 田 中 2004).

また, 1990 年代以降, 産業集積に競争優位をむ たらす知識創造や学習, イノベーションの重要性が 指摘されている。集合的な学習や不確実性の削減と いった「ミリュー」の役割に注目したCamagni （1991）らの議論や，集積地域を知識創造と学習の 場としてとらえるFlorida（1995）らの「学習する 地域」論が展開され, 日本においてもこのような議 論が紹介・検討された（松原 1999; 友澤 2000; 宮 町 2003; 山本 2005). 
知識・学習に着目して企業間関係とその技術的存 立基盤を議論した研究（藤田 2007）むみられる一 方で, 地方自治体（以下，自治体）や大学，公設試 験研究機関（以下，公設試）等の非企業的主体が産 業集積の発展に果たす役割が注目されている。その ため, 産業集積地域における知識創造や学習, イノ ベーションに関する議論は,「企業間関係」を中心 としたものから，多様な主体から構成される「主体 間関係」へと拡大している。議論する主体の多様化 とともに, その関係で議論される内容も, 取引関係 だけではなく技術協力や知識の波及にまで拡大し, 変化を遂げている.

本稿では, 産業集積地域における産学官連携の進 展について取り上げ, その主体間関係の変化を, 以 下 2 点に留意して検討する.

第 1 に, 企業の規模による産学官連携の差異に留 意する，産業集積地域における産学官連携の進展に 関する実態研究は, 徐々に進んでいる（堂野 2004; 松橋 2004; 末吉・松橋 2005; 岡本 2007). その多 くは，産学官連携の支援システムに主眼が置かれて おり, 企業に対する実態調査に基づいた研究は少な い. 本稿では, 産学官連携が産業集積の質的変化に 果たしつつある役割を明らかにするために, 企業に 対する実態調查を行った。 その際, 自社内に研究開 発機能を持つことが少ない中小企業と逆にそれが多 い大企業とでは, 産学連携の有り様が異なると考え られるため, 企業の規模による差異に留意した。

第 2 に, 地域的コンテクストに対する考慮の必要 性である。産業集積地域の産業支援システムを検討 した末吉・松橋（2005：38）は，「支援システム自 体が, 地域産業之同様に, 経路依存的な存在」であ り, 地域的コンテクストを考慮することの必要性を 主張している。地域で形成されている主体間の関係 は一朝一夕に築かれたものではなく従来築かれてき た主体間関係，たとえば産学官連携においては企業 間関係や，大学と企業・自治体との関係を基盤とし
ていると考えられ, 本稿でもこの点に配慮する.

以上を考慮し本稿では, 産学官連携による主体間 関係の変容に関する実態解明を通じて, 産学官連携 が産業集積の質的変化に果たしつつある役割につい て考察する.

本稿では, 企業城下町である山口県宇部市を事例 に取り上げる. 企業城下町は, 多数の中小企業が集 積する大都市型産業集積地域や産地とは異なり, 単 独あるいは少数の中核的な大企業 (以下, 中核企 業）と多数の中小企業という明らかに規模の異なる 企業が一体となり形成されている産業集積地域であ る. それらの企業は, 圧倒的な影響力を有する中核 企業を頂点とし主に域内のみで取引が完結する閉鎖 的な取引関係を形成している。このため, 企業城下 町は中核企業と下請企業との間で歴史的に構築され てきた関係や，産学連携の有り様に対する大企業と 中小企業との差異の考察に適していると考えられる. 成熟した産業集積地域では, 主体間の関係が硬直 化しており, 硬直性の打開が重要な課題となってい る.ルール工業地域の衰退について検討した Grabher（1993）は, 過去に産業集積が獲得してきた優 位性がイノベーションにとって強い障害となるロッ クインに注目し，ロックイン解放の必要性を主張し た. 企業城下町においても, ロックインの解放は重 要な問題である. 特に 1990 年代以降, 企業城下町 の中核企業は, 事業の「選択と集中」を迫られ, 長 年取引のあった中小企業との関係を見直さざるを得 なくなっている. 他方, 中小企業は, 特定企業への 依存度を低め, 下請企業からの自立化を迫られてい るが, 新製品の開発経験の欠如, 営業のノウハウの 欠如等, さまざまな問題点があり, 状況の改善に至 っていない，こうした中，主体間関係の再構築によ り, 閉塞感漂う企業城下町の改善を試みる動きが各 地でみられている. 岡山県玉野市では, 中小企業の 技術を生かして企業グループを結成し販路拡大や新 分野進出に挑戦している (関・岡本 2001). 茨城県 


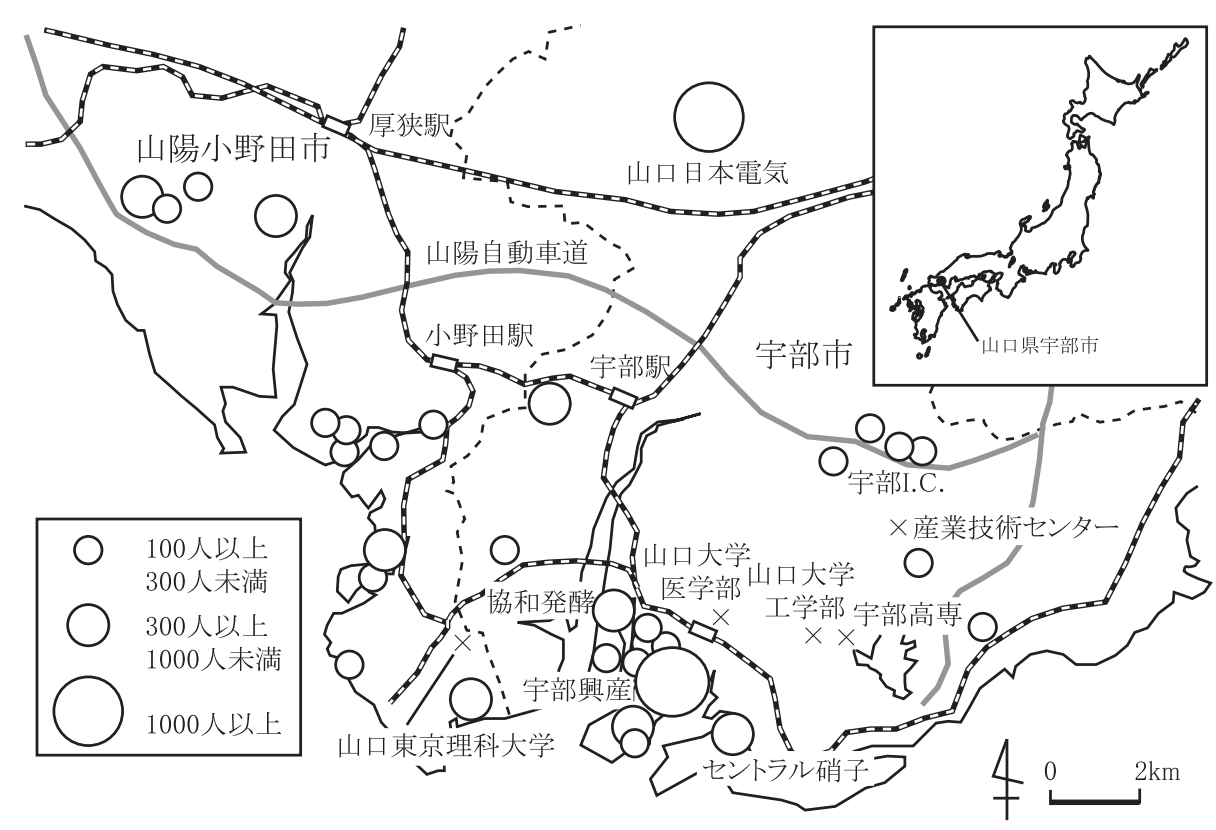

図 1 対象地域の位置と主要工場, 大学・研究機関の分布（2005 年）

(各社有価証券報告書, 各社ウェブサイトにより作成).

Fig. 1 Location of study area and distribution of main factories, university, and research laboratories, 2005

日立市では，ブランド力が劣り流通網が不足する中 小企業の連携に中核企業が関与する動きがみられる (遠山 2002)。宇部市における産学官連携もこのよ うな動きの一つとして位置づけられる。

対象地域である山口県宇部市5) は，宇部興産株 式会社 6) (以下, 宇部興産) の企業城下町 7) とし て知られる都市である (図 1)。宇部市には, 山口 大学 8) の工学部と医学部や宇部工業高等専門学 校9）(以下，宇部高専）等の学術機関がある. 地方 国立大学の中であ山口大学の民間企業等との共同研 究数が著しく多い10）ように産学連携が積極的に展 開されており, 宇部市の産学官連携は, 産業集積地 域におけるその先駆的事例としてみることもできる. 宇部市に関する既存研究として, 石炭産業が隆盛を 誇った明治期から戦前を対象とした研究（森 1977; 太田 1998，1999；武田 2000）や戦後の工業都市と しての変容を記述した研究（林 1968；北田 1991； 岩間 1991，1992，1993；三浦 2004）がある.
本稿では前述した目的を明らかにするために以下 のように議論を進めた。 II では, 石炭産業の盛衰と 中核企業の設立の経緯や企業戦略の動向について概 観した上で，従来の主体間関係について，企業間関 係および大学と企業・自治体との関係を中心に検討 した. III では, 1990 年代以降の産学官連携による 主体間関係の変容について論じた。具体的にはまず, 大学や自治体が産学官連携に取り組む要因に注目し て産学官連携支援システムの形成過程を検討した。 次に，宇部市における代表的な産学官連携「知的ク ラスター創成事業」を取り上げ，地域的な連携の形 成過程を明らかにした。さらに，企業規模による産 学官連携の差異を分析した.これら産学官連携の進 展と産業集積の質的变化について, 産学官連携の地 域的コンテクストに留意しながら考察した. IVで は，これらの分析をまとめ結論を述べた。

本研究の遂行においては，宇部市史（宇部市史編 纂委員会 1966 ；宇部市史編集委員会 1993）や宇部 
興産社史（宇部興産株式会社 1998）, 有価証券報告 書およびさまざまな統計を用いた。また，宇部興産 をはじめとする産学連携に関わる企業のほか, 山口 大学, 山口県商工労働部, 宇部市工業振興課, 宇部 商工会議所, 山口県産業技術センター, やまぐち産 業振興財団に聞取り調査を実施し情報を収集した。 聞取り調查は, すべて 2005 年 5 11 月に実施した.

\section{II＼cjkstart産業構造の転換と従来の主体間関係}

1. 産業構造の転換と中核企業の变化

1）石炭産業の盛衰と中核企業の形成

宇部11）は，近世以降石炭の産出地として栄え， そこで蓄積された資金が近代工業の礎となってきた。 明治期の宇部では，地縁・血縁的な共同体組織によ って石炭が採掘された。1 897 年に設立された「沖 ノ山炭鉱組合」は, 共同体組織の中心人物であった 渡邊祐策を組合長とする匿名組合組織であった（森 1977；太田 1998；武田 2000).

第一次世界大戦を経て，宇部の石炭産業は飛躍的 に成長した。渡邊は，石炭産業で蓄積した資金を基 に，1914 年に宇部新川鉄工所，1917 年に宇部紡績 所, 1923 年に宇部セメント製造を相次いで設立し た。さらに 1933 年, 本格的に化学工業へ参入し, 宇部窒素工業が設立された。このような事業の多角 化は,「有限の石炭から無限の工業へ」という渡邊 の考え12）に基づいていた。また，渡邊は企業と地 元の発展を同軸でとらえる「共存同栄」を経営理念 に揭げ，学校や鉄道などの社会基盤整備にも尽力し た. 1942 年に, 戦時産業再編政策に応じて, 沖, 山炭鉱，鉄工所，セメント，窒素の 4 社を合併し宇 部興産株式会社が設立された。戦後しばらくの間, 石炭部門は活躍したが 13), 1960 年代後半以降, 石 炭需要の減少に伴い炭鉱の閉山が相次いだ。

2) 企業戦略の变化

宇部興産の基幹事業であった石炭部門が斜陽化す る中, 同社は高度経済成長期以降, 企業戦略を転換
し，新事業・他地域へ進出した，すなわち，同社は セメントなどの建設資材部門を積極的に拡大すると ともに, 石油化学事業や金属成形事業への進出を図 った。千葉県市原市（1964 年設立）および大阪府 堺市（1971 年設立）のコンビナートに石油化学工 場を新設した。同社が宇部以外の地域に進出した理 由として, 大消費地に近く新たな需要を見込め, 在 京・在阪の他企業との相乗効果によって技術革新 · 製品開発につながる期待があった（宇部興産株式会 社 1998)。また, 同社は 1980 年代後半以降, アメ リカ, タイ, スペイン等に進出し, 石油化学や金属 成形の工場を建設した。

同社は生産拠点を拡散させる一方で，本社機能を 宇部本社から東京本社へ移転した。宇部興産の登記 上の本社は, 2008 年現在屯, 宇部市に置かれてい るが，1980 年代以降，経営上の重要な決定事項は 東京本社でなされるようになったといわれており (岩間 1991), 本社機能の中枢である管理機能は東 京本社に置かれている (田中 2002). 現在, 東京本 社は管理・営業機能を, 宇部本社は生産・労務・研 究開発機能を担っている.

このように同社は, 生産拠点の拡散や本社機能の 東京移転によって「宇部からの離陸」を進めてきた。 しかし, 生産拠点の拡散が進展したとはいえ, 2005 年現在でも宇部地区 14) にある同社事業所の従業員 数は同社総従業員数の $69 \%$ を占め, 同社の研究開 発機能の中枢である宇部研究所や高分子研究所が宇 部市に存在するように, 宇部市は同社にとって現在 でも重要な生産・研究開発拠点である.

\section{2. 主体間関係の形成之展開}

1）企業間関係

宇部市において大規模工場の設立・進出が顕著で あったのは, 石炭産業が隆盛を極めていた戦前から 1950 年代までと 1970 年代後半〜 1980 年代とに分け られる. 前者の時代には, 宇部興産, セントラル硝 


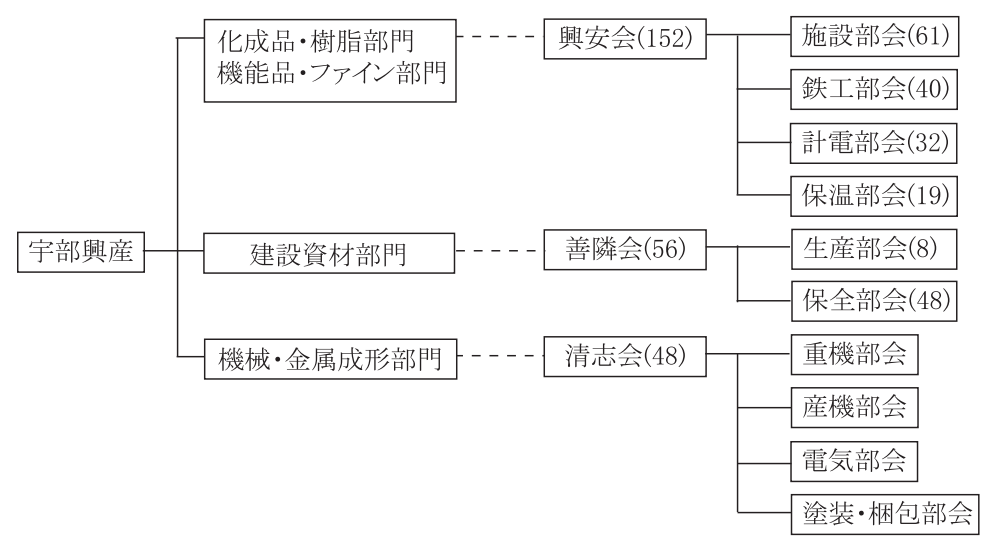

図 2 宇部興産の協力会組織（2005 年） 括弧内の数字は, 企業数を示す.

(聞取り調査により作成).

Fig. 2 Organization of subcontractors in Ube Industries, 2005

子，協和発酵工業をはじめとする大規模工場が同市 臨海部に設けられた，後者の時代には，山口日本電 気をはじめとする大規模工場が，同市郊外の丘陵地 に造成された工業団地に建設された。

産業集積として企業城下町をみた時, 鉄鋼, 化学 等の自己完結型生産体系を特徵とするすのと, 輸送 用機械，電気機械等の下請分業生産体制を特徵とす るあのとに類型化できる（伊藤 2003：173）。中核 企業である宇部興産は, 化学, セメント, 機械等の 多様な事業を展開しているため, 宇部市の下請構造 は両類型の中間に位置づけられる.

宇部商工会議所（1996）によると，宇部市内の中 小製造業者の多くは, 戦前から 1950 年代に創業し, 宇部興産や中小炭鉱を取引相手とした炭鉱機械製 作・補修業を起源としている。 その後, 鉱業の衰退, 化学工業の発展とともに, 親企業の要請に応えたプ ラント向けの製造装置の製作, 組立, 据付, メンテ ナンス等を行い, 個別受注生産形態をとってきた. そのため中小製造業者は, 専属下請的色彩が強い. 特に宇部興産の下請企業が多く, それらの企業は宇 部興産の事業部門ごとに, 安全協力活動等を行う協 力会を結成している (図 2). 下請企業のほとんど は宇部市およびその周辺に立地する中小企業である.
1995 年に行われた「宇部市工業実態調査」では, 市内中小製造業の約半数の企業が出荷額の $50 \%$ 以 上を親企業に依存しており, 親企業に $50 \%$ 以上依 存している企業のうち,「現状程度の依存度を維持 したい」,「さらに依存度を増やしたい」とする企業 が $64.6 \%$ を占め, 「取引先を増やし一社あたりの依 存度を減じたい」とする企業は $35.4 \%$ であった。 これは,この地域で数十年間にわたり構築されてき た仕事の受注の方法や下請企業において形成されて きた意識に起因すると考えられる。つまり，「専属 下請企業は親企業の指示通りに品質・納期・価格を 守っていれば自動的に仕事は与えられ，情報力・営 業力を充実し積極的に営業活動をする必要」(宇部 商工会議所 1996：25）がほとんどなく，「長年企業 城下町として下請企業が安定的に発展してきたため, その意識が濃厚に定着している」(宇部商工会議所 1996：25)。このように従来の主体間関係は, 宇部 興産とその下請企業から構成される垂直的な構造で あった.

情報獲得力や営業力の欠如といった下請企業の課 題は, 中核企業の業績が悪化した時に顕在化する. 1990 年代後半, 宇部興産は業績が悪化したため, 構造改善を迫られた。同社は, 収益構造の改善を目 
指して，1999～2001 年度の中期経営計画「21 • UBE 計画」を策定し, 機械・エンジニアリング部 門のうち, 大幅赤字の続くエンジニアリング事業か ら撤退し，機械事業を分社化した。また，公共事業 削減で受注が減少した建設資材部門の合理化を図っ た. 一方, 今後屯収益力向上が見込める金属成形や 化学部門では, 事業が拡大された。

1990 年代の宇部興産の業績不振は, 宇部市の製 造業全体にも影響を与えた。「宇部市統計書」によ ると, 1990 年には 349 工場があり 13,246 人が働い ていたが, 2002 年には 228 工場, 従業者数 10, 693 人となり,「工場数」で $35 \%$,「従業者数」で $19 \%$ 減少した. 規模別で見ると, 従業者数 4 9 人規模 の工場で「工場数」,「従業者数」とも最屯減少率が 高い.「製造品出荷額等」で見ると, 1990 年から 2001 年まで漸減傾向が続いていたが, 2002 年に大 企業を中心に進められた構造改善が結果として現れ 始めている.

このように宇部市では 1990 年代に, 大企業, 中 小企業ともに厳しい状況に陥ったため, 地域全体で 危機感が形成されていった。この危機感は, 産学官 連携を進展させた背景の一つになったと考えられる。

2) 大学と企業・自治体との関係

宇部市は, 企業城下町であると同時に大学を有す る都市であある。これまで構築されてきた大学と企 業・自治体との関係は, 今日の産学官連携の基盤と なっている。

1940 年前後に, 宇部市に現在の山口大学の前身 となる学校が設立された。1938 年に, 官立高等学 校の設立が計画された際に, 当初設立予定であった 山口市が財政上，資金・学校用地を提供できなかっ たため, 工業都市として成長著しい宇部市が学校の 誘致に成功し, 沖ノ山炭鉱組合等の地元企業の多額 の寄付金を受けて, 宇部高等工業学校（現在の山口 大学工学部) が設立された。また，1944 年に政府 の要請により, 山口県立医学専門学校 (現在の山口
大学医学部）が宇部市内に設立された。同校は県内 各地から誘致されたが, 渡邊剛二宇部興産社長の尽 力により, 宇部市に決定された（宇部市史編集委員 会 1993; 松野 2005). 戦後, 宇部高等工業学校は 新制山口大学に組み込まれ, 山口県立医科大学 15) 屯山口大学医学部に移管された。このほか, 1960 年に宇部短期大学 16), 1962 年に宇部高等工業専門 学校が開学した。このような学術機関の充実化は, この規模の地方都市としてあまり例がなく, 特異な 状況といえる.

宇部市では, 1950 年代に公害対策を通じて産学 官連携が構築された。 宇部市は, 戦前から煤煙問題 を抱えていたため, 1950 年, 当時の山口県立医科 大学に委嘱しその実態を調查した。 その調査結果を あとに, 宇部市は降灰の取締り条例を制定し, 企業 は集塵装置を取り付け, 徹底的な污染対策に着手し た. 山口大学工学部屯公害対策の技術指導に協力し た。この宇部市の産学官が連携した大気污染対策は 「宇部方式」と呼ばれるほど先進的なものであり， その後の公害対策のモデルとなった（師井 1967; 林 1968; 森 1977).

また，宇部市およびその周辺市町村はテクノポリ スや頭脳立地地域に指定され, 産学官連携の基盤作 りが進められた。 1984 年に宇部市を母都市とする 4 市 4 町は, テクノポリス地域に指定され, 1992 年 に宇部市および周辺の 3 市 1 町は, 頭脳立地地域に 指定された。テクノポリス計画は, 1984 年から 2000 年にかけて進められた. 1992 年から 2000 年ま での山口地域集積促進計画（頭脳立地計画）とあわ せて, 2005 年まで山口地域高度技術産業集積活性 化計画が経過措置として行われた.この間, 宇部市 内に大学や研究機関が誘致された。1987 年に東京 理科大学山口短期大学が開学し, 県メカトロ技術セ ンターが設置された. 1990 年に超高温材料研究セ ンター17）が設置された。1999 年に県産業技術セン ターが山口市から宇部市に移転した。 国勢調查報告 
によると宇部市内の科学研究者は, 1980 年に 110 人であったが，1990 年に 369 人，2000 年に 480 人 に増加した，宇部地域におけるテクノポリスは，工 場の誘致による工業振興という点では目標に達しな かったが 18), 学術・研究機関の充実化が図られ, 今日の産学官連携の基盤形成に寄与している.

宇部地域のテクノポリス計画指定の際に, 山口大 学工学部が,「学」の中核として位置づけられたこ とを契機に, 1980 年代後半以降, 山口大学は地元 企業と共同して多様な研究を進め, 商品化・事業化 につながる産学連携に取り組み始めた（山口大学工 学部 1990). 山口大学工学部は, 1985 年に土木 ・ 建設工学科の研究者が科学技術を解説した公開講座 「工学部市民セミナー」を開設し, 同年以降屯各学 科持ち回りで公開講座が開かれた. 1986 年, 地元 中小企業と大学の研究者が意見交換する産学合同懇 談会が開催された。1989 年, 山口大学工学部に, 地域の企業との接点となる科学技術相談室が設置さ れ, 徐々に大学々地元企業之の交流が進められた.

宇部興産屯,このテクノポリス計画に対して強い 関心を寄せていた。 1983 年, 同社は社長直属のテ クノポリス対策室を設け，政府指定の段階から全面 的に協力した。 同社はテクノポリス計画の中枢組織 であった山口県産業技術開発機構に出資し人材を派 遣した。ささらに同社は電子機器メーカーや東京理科 大学, 超高温材料研究センター等の誘致にも積極的 な役割を果たした。同社がテクノポリスに関わった のは, 地域貢献であると同時に, 同社製品の高付加 価值化を進める戦略と符合したためであった（宇部 興産株式会社 1998)。同社は, 山口大学工学部の基 礎研究力に期待して, 同社の研究補完や両者の研究 促進を図るため 1980 年代から共同研究を実施して きた。両者間の共同研究は, 1982 年から 1998 年ま で 87 件実施された。この間, 同社は, 山口大学工 学部に対して奨学寄附金を支出し, 共同研究による 特許を 22 件出願した. 同社は, 山口大学医学部に
医薬品の研究開発のため研究員を派遣したこともあ るが, 共同研究は工学部との間でのみ行われた。

1980 年代から 1990 年代前半に扮いて, 大学と企 業とが共同研究を行う際は, 個々の大学の研究者と 個々の企業との間で, 共同研究の成果の取扱いに関 する契約が結ばれていた。個別対応ではなく全学的 組織による対応は, 1990 年代後半以降であった.

以上のように，第 1 に 1940 年前後に，宇部市に 現在の山口大学の前身となる学校が設立されたこと, 第 2 に 1950 年代に産学官が連携して公害対策に取 り組んだこと，第 3 に 1980 年代にテクノポリスに 指定され，学術・研究機関の充実化が図られるとと もに，大学と地元企業との交流が始まったことが, 今日の産学官連携の基盤となっている.

\section{III 産学官連携による主体間関係の変容}

1. 産学官連携支援システムの整備

1）大学の産学官連携支援システムの整備

1990 年代以降, 山口大学では, 広中平祐学長を 中心に，先駆的な産学官連携支援システムを急速に 整備してきた. 1991 年に地域共同研究開発セン夕 一が，1995 年にベンチャービジネスラボラトリー が，2002 年にビジネスインキュベーション施設が 設置された。同年にはそれらの対外的な空口の一本 化之関係組織の一元化のため, 産学公連携・創業支 援機構が設けられた。また，山口大学の教員の出資 による研究成果の特許出願を目的とする山口 TLO の設立（1999 年）や, 教職員の創出する知的財産の 機関帰属決定 (2002 年), 知的財産本部の設置 (2003 年) 等, 知的財産関連のシステムも整備された。

同時に, 山口大学は 1997 年に地元民間企業との 共同研究の推進のために, 地域共同研究開発セン夕 一内に「研究協力会」を設立した。 2005 年現在, 企業・団体 104 社汃研究協力会に参加している. 山 口大学の研究協力会は, 地元中小企業が多数参加し 地域との結びつきが強い19). 研究協力会は業種ご 
$(\%)$

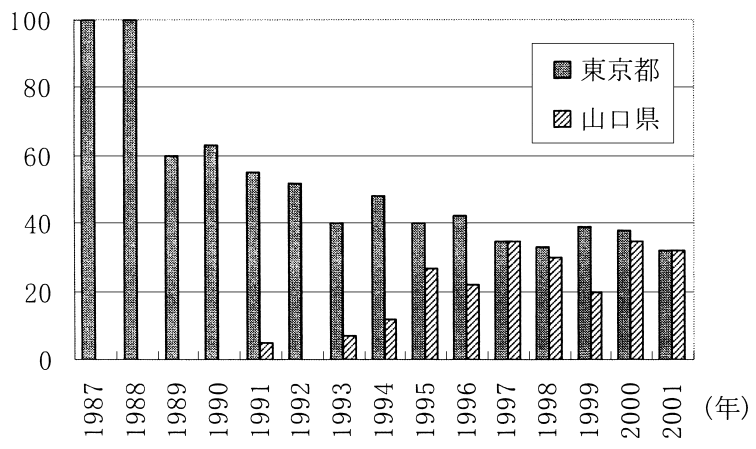

図 3 山口大学の共同研究相手企業の本社所在地別 推移

(文部科学省科学技術政策研究所（2003）による)

Fig. 3 Trend in headquarters' location of enterprises conducting joint research with Yamaguchi University

とに, 環境, 生産・情報, 有機材料, セラミックス 材料, 真空技術 - 薄膜プロセス, 建設, 医療・福祉, フード・バイオ，メディア・ネットワーク， MOT (技術経営）の 10 部会がある. 各部会では年に数回, 先端技術に関する講演会や発表会が実施されている.

このような整備に伴い, 山口大学の産学連携は目 覚ましい結果を残している。1996 年から 2005 年の 共同研究契約の総件数において, 山口大学は地方国 立大学の中で最も多い20). 山口大学は, 山口県内 の地元企業との共同研究数を増やして総件数を伸ば してきた. 山口大学の共同研究相手企業を本社所在 地別に見ると，1980 年代はほとんどが東京都であ ったが，1990年代前半から山口県に本社を置く地 元企業との共同研究が増加した. 1990 年代後半以 降は, 東京都に本社を置く企業と山口県に本社を置 く企業がそれぞれ半数を占めている(図 3). これ は当初, 主に東京都に本社を置くような域外の大企 業との共同研究が多かったが，連携支援システムの 充実や中小企業の産学連携に対する意識の高まりに より, 地元中小企業との共同研究が増えているため である。

山口大学が産学連携に取り組んでいる最大の要因
は, 国立大学の法人化に伴う新たな研究資金の確保 である. 2004 年, 国立大学が法人化され, 大学は 自助努力によって外部資金を確保する必要に迫られ ている. その有効な手段として産学連携が注目され ている.しかし, 地方圏の大学は産学連携を行いた くても大学周辺に共同研究の相手となるような大企 業が少なく, 大企業が大学周辺に多い大都市圈のそ れと比べて困難な状況にある.このため, 山口大学 は後述するように地元大企業と包括的に連携すると と屯に，地元中小企業と多数の共同研究に取り組む 戦略をとった21). 山口大学 (2005) によると, 2004 年度の収入のうち「産学連携等研究収入及び 寄附金収入等」は 24 億 9600 万円の収入を得ており, それは総収入の $6.5 \%$ を占める. 今後, 運営費交付 金の減少が予想されているため, 産学連携による外 部資金の導入は今後一層重要な意味を持つ。むちろ ん，資金的な動機だけではなく，社会貢献のため自 らの研究成果の提供に協力的な大学の研究者屯増加 している.

2) 自治体の産学官連携支援システムの整備 宇部市でも産学官連携支援システムが整備されて きた. 1993 年以降, 宇部市長を務める藤田忠夫は, 初当選時から大学を活用した新産業創出を選挙公約 に掲げていた。 1996 年に宇部商工会議所がまとめ た工業振興ビジョンに新産業創出の方向性が示され たことや，1997 年に国連環境計画より 1950 年代の 公害対策「宇部方式」に対して宇部市が表彰された こと22）が契機となり，支援システムの整備が本格 化した. 1998 年, 宇部市が主導して, 医療福祉, 環境, 情報の 3 分野にわたる「産学官による分野別 研究会 23) 事業」が始まった. その後, 研究会や協 力会, 協議会が相次いで設立され, 補助金・助成金 制度や施設の整備屯進んだ。

山口県においても産学官連携支援システムが整備 されてきた. 山口県は 2002 年に「産学公連携イノ ベーション創出推進委員会」を設立し，連携推進に 
向けた計画を策定した。このほか，県の外郭団体 「やまぐち産業振興財団 24)」は, 後述する知的クラ ス夕ー創成事業の運営に関わり, 公設試「山口県産 業技術センター」は, 大学々の連携が困難な小規模 企業に対する技術力の底上げ支援を行っている.

自治体が産学官連携に取り組む要因として，第 1 に財政状況の悪化が挙げられる.「宇部市統計書」 によると，宇部市における一般会計の歳入のうち， 市税は 1988 年度以降，20２4 億円程度で伸び悩ん でいる。これは 1990 年代以降の法人市民税の落込 み 25）のためである. 1990 年代以降，市税の減収分 を埋め合わせるために，市債や地方交付税に対する 依存が高まっている. 1990 年代後半以降, 市債, 地方交付税と屯に歳入総額に占める割合がそれぞれ 10\% を超えている. 税収の増加が期待される産学 官連携による新産業創出に対して注目されている.

第 2 に，基礎素材型産業に特化した産業構造である。 工業統計表の「製造品出荷額等」を業種別に基礎素 材型, 加工組立型, 生活関連型 26) に 3 分すると, 2000 年現在，全国では基礎素材型が 33. 3\%，加工 組立型が $46.0 \%$, 生活関連型が $20.7 \%$ であるのに 対し, 山口県では基礎素材型が $70.2 \%$, 宇部市で は基礎素材型が $77.8 \%$ と，山口県，宇部市ともに 基礎素材型産業に特化している，基礎素材型産業は 機械化が進みやすく雇用の増大が見込めないため, 山口県技よび宇部市は, 産学官連携の進展によって, 加工組立型産業を創出・育成し雇用の増大につなが る産業への転換を進めている.

3）産学官交流会の開催

大学や自治体で産学官連携支援システムの整備が 進む一方で, それ以外の主体 27) の中にも産学官連 携を円滑に進める仕組みを形成しようという機運が 高まった。その動きの一つが「産学官の有志が気軽 な雾囲気で宇部の活性化について話し合う場を設け ること」28）を目的とする産学官交流会「キューブ (C-UBE) サロン」である.このサロンの特徵は,
企業の規模や業種にとらわれず宇部市内の産学官連 携に関わるあらゆる主体が参加していることである. サロン参加の条件は, 宇部市およびその近郊に事業 所を持つ企業であり, 幹事会社の推薦が必要である. 参加企業の資格は, 設立当初, 中小企業に限定して いたが，2005 年 3 月から大企業も参加できるよう に改め, 宇部興産や山口日本電気も参加している. 2005 年現在の会員は, 産が 58 社, 官が 18 団体, 学が 9 団体であり, 銀行や信用金庫, ベンチャーキ ヤピタル, 特許事務所も参加している. 交流会は, 前半・後半の 2 部から構成され, 前半は各回特定の テーマに関する専門家の講演会が，後半は産学官が 名刺を配り互いの情報を交換する懇親会が開かれて いる。キューブサロンでは，新市場の開拓に必要な 情報や産学連携支援制度に関わる情報のほか, 先端 的な技術が紹介される。しかしそれ以上にこのサロ ンの重要な役割は, 地域全体の意識の共有である. このサロンは, 業種や規模に関わりなく多様な主体 が参加しているので, 各参加者が地域内の動きを知 るとともに地域全体の方向性を共有できる，産学官 交流会の開催により, 宇部市における産学官連携は, 「地域ぐるみ」の動きとなっている.

\section{2. 医工連携と知的クラスター創成事業}

宇部市に打ける産学官連携の中で, 医工連携を核 とした医療福祉分野の製品開発が重点的に取り組ま れている. 山口大学では, 1997 年頃から先端的な 医療に積極的な医学部スタッフが工学部に対して医 療機器開発の共同研究を申し入れたことを契機に, 医工連携は始まった。（日本政策投資銀行中国支店 2002). 1998 年, 山口大学地域共同研究開発セン夕 一の研究協力会に, 医療・福祉部会が設置された. それまでの研究協力会は工学部の研究者と地元企業 との連携の場であったが, 同部会には医学部の研究 者が加わり, 医学・工学・企業の 3 者連携が実現し た。 その後も両学部の研究者は議論を重亦, 医工連 
携に関わる研究教育組織の構築を模索した。その結 果, 2001 年, 医学々工学々を融合した大学院医学 研究科応用医工学系独立専攻が開設された。

医工連携は，2000 年前後から自治体が支援し地 元企業が連携に加わることで輪を拡げていった。山 口大学内で進展していた医工連携に注目した宇部市 は，これを新産業創出に波及させるため，「産学官 による分野別研究会事業」の一つとして，1999年 「うべ医療福祉産業研究会」を発足させた。この研 究会の目的は, 市が持つ企業とのネットワークを使 い, 医学部や付属病院が持つ先進医療情報・ニーズ と工学部が持つ技術, 地元企業が持つ技術とをマッ チングさせる場の提供である. 約 2 力月に 1 回開催 の研究会に, 自治体, 地元企業, 山口大学医学部 · 工学部の研究者, 山口県産業技術センター, 医学部 付属病院の看護士等が参加している。 また, 1999 年度から 2002 年度の間に, 文部科学省の地域研究 開発促進拠点支援事業 29) (RSP 事業) が山口県内 で実施された（中国産業活性化センター 2001）。こ の事業のうち医療・福祉分野では, 地元企業と連携 した医療福祉機器の研究開発が行われ, 知的クラス ター創成事業につながったものあある（三木 2003）. さらに 2003 年, 宇部市は医療福祉分野の新産業創 出促進のために, 山口県と経済産業省の支援を受け, 山口大学医学部隣接の市有地にインキュベーション 施設「メディカル・クリエイティブ・センター30)」 を建設した。

医工連携は, 病院用ベッドの改良といったローテ クなものから最先端技術を駆使したハイテクなもの までさまざまなレベルで行われている。このうち, 事業化できる有望な研究が LED (発光ダイオード) を用いた医療機器開発であった。工学部の田口常正 教授と内視鏡に詳しい医学部の研究者とが連携して, 高輝度・高演色性 LED および近紫外 LED の医療 分野への応用研究を続けていた. 2001 年, 文部科 学省からの「知的クラスター創成事業」募集の際に,
山口大学や自治体は, この研究を軸にしたクラス夕 一創成を目指した (三木 2003). その後, 宇部地 域 31) は 2002 年度および 2003 年度に知的クラス夕 一創成事業試行地域 32) に指定され，2004 年度から 2008 年度まで事業実施地域に指定されている。こ の間, 県の外郭団体「やまぐち産業振興財団」は, 2002 年に知的クラスター創成事業の運営組織「知 的クラスターセンター」を山口大学地域共同研究開 発センター内に設置し, 2003 年度から「知的クラス 夕一研究成果事業化促進補助金 33)」制度を設けた.

宇部地域における知的クラスタ一創成事業は, 「高輝度・高演色性 LED 等光技術を活用して, 次 世代医療機器を開発し, 新産業の育成を図る」とい う構想のもと,「高輝度 LED 技術を基盤とする医 療用光源システムの開発」を基幹として, 医療光源 システム, 低侵襲治療機器, 高性能診断機器に関す る研究開発を進めており, 企業 19 社 (2005 年現 在）と大学, 公設試が参加している(表 1). 企業 の内訳は, 県外企業が 9 社, 県内企業が 10 社であ る. LED の研究開発の実績がある企業が県内に少 なかったため, 宇部興産を除く県内企業はすべて中 小企業であり，県外企業のほとんどは LED に関す る技術を有する大企業 34) である. このように, 宇 部市における医工連携を核とした医療福祉分野の製 品開発に関わる連携は, 大学や域外企業が有する知 識や技術を活用して進められている。

\section{3. 企業規模による産学官連携の差異}

産学官連携の具体的な事例を通じて, 産学官連携 の要因と企業にとっての産学官連携の意義を, 企業 規模ごとに分析する.

1）大企業にとっての産学官連携

大企業として宇部興産の産学官連携を取り上げる. 2000 年代以降, 宇部市において, 大学と大企 業・自治体之の包括的連携が締結されている. 包括 的連携とは, 研究室あるいは学部単位ではなく, 機 
表 1 知的クラスター創成事業の参加組織

Table 1 Actors in “Intellectual Cluster Program” in the Ube region

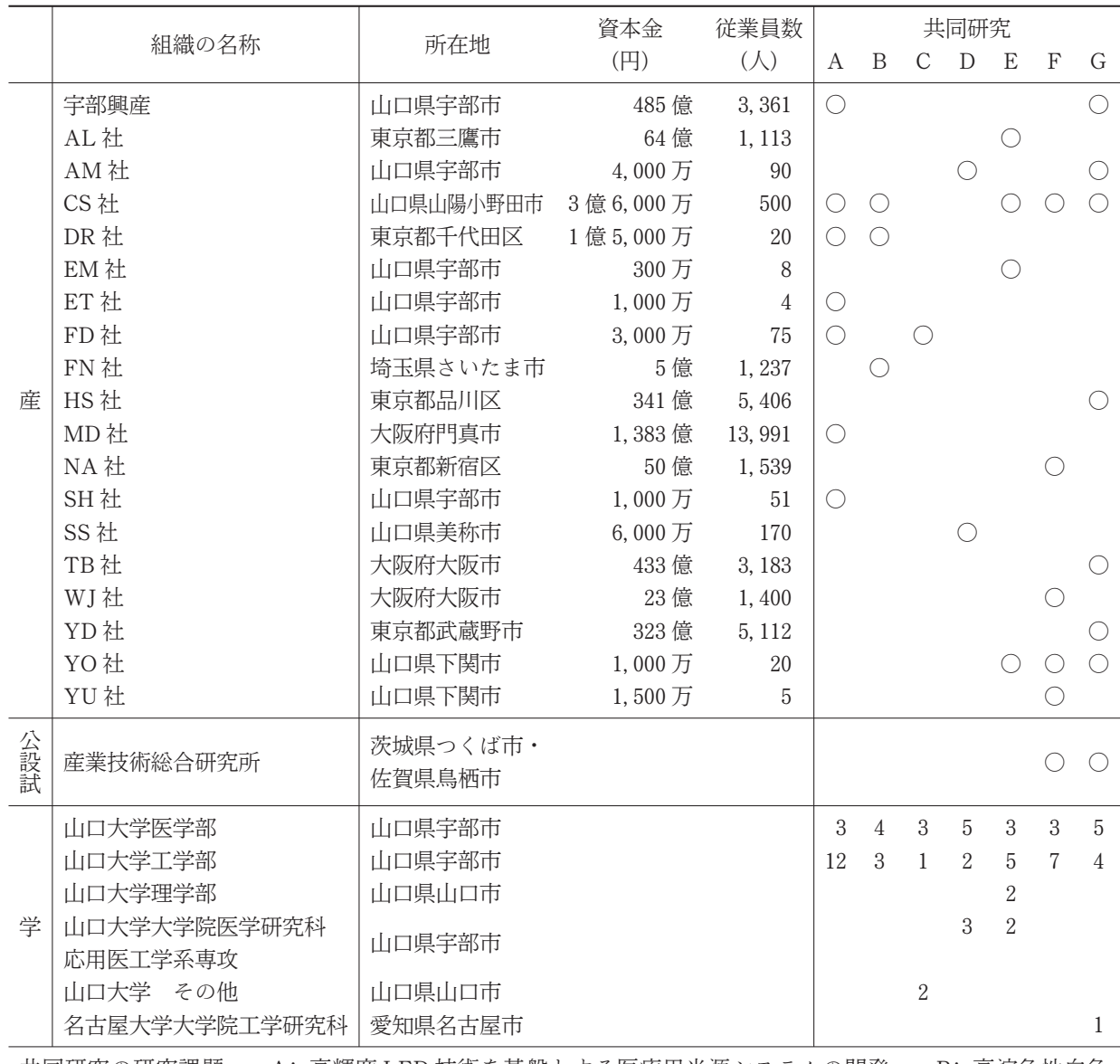

共同研究の研究課題 $\mathrm{A}$ ：高輝度 LED 技術を基盤とする医療用光源システムの開発 $\mathrm{B}$ ：高演色性白色 LED を用いた内視鏡の開発と消化器疾患の診断・治療への応用 C : 高照度白色 LED 照明装置の開発と精神 疾患の診断・治療への応用 D：LEDの低侵襲手術ナビゲーションシステムへの応用 $\quad E$ ：近赤外線, 超 音波等を利用する高性能動脈硬化診断システムの開発 F：LED 等を利用する高感度血管病診断機器の開発 G：蛍光量子ドット，LED を利用する高精度・高速細胞解析システムおよび免疫診断機器の開発

「産」「公設試」の○印は, その組織が参加していることを示す.「学」の数字は, 参加研究者数を示す.

(『知的クラスター創成事業 事業成果報告書 2004 年度版』により作成)。

関対機関の連携であり，研究分野を限定せず，研究 や教育等多方面にわたる連携を目指すむのである. 大学の法人化前後加ら, 全国の大学と企業・自治 体・金融機関との間で，相次いで包括的連携が結ば れている. 山口大学は, 2004 年に宇部興産, 国際 協力銀行, トクヤマ徳山製造所, 山口銀行, 宇部市, 2005 年に宇部高専, 山口市, 2006 年に国土交通省 中国地方整備局との間で包括的連携協定を締結した.
山口大学の包括的連携の特徵は，地元の金融機関や 自治体，地元に所縁のある企業等，地域との結びつ きの重視である。一方，宇部興産は，これまでの信 頼関係や，地の利，同社の企業精神である「共存同 栄」等を総合的に考慮した結果，山口大学と包括的 連携を締結した。包括的連携の締結により，主体間 の関係は一層強化されている. 山口大学・宇部興産 株式会社（2006）によると，山口大学と宇部興産と 
は, 包括的連携協定の締結以後, 主に以下 3 点の連 携に取り組んできた。第 1 に, 研究開発の連携であ る. 両者は,「炭酸ガス抑制・削減技術の開発」を 中長期的な特定テーマとして取り上げており，山口 大学が有する化学や環境共生工学の保有技術と, 宇 部興産が有する「C1 ケミストリー（一酸化炭素利 用技術) 」や廃棄物リサイクル技術とを融合させて いる. 両者は特定テーマ以外の多様な研究開発テー マにも取り組んでおり，それらの成果に基づき，当 初計画数を超える特許が生み出された. 第 2 に, 技 術・人材の交流である. 両社の研究交流会「RT (研究・技術) プラザ」をはじめとする交流により, 包括的連携締結後の共同研究数（2006 年）は, 締 結前の 2003 年の 5 倍以上に及んだ。第 3 に, 人材 育成である。宇部興産の協力により山口大学で「知 的財産インストラクター養成講座」を開講したほか, 大学院生の企業内長期インターンシップを共同研究 に関連させて実施した。包括的連携の締結によって, 山口大学と宇部興産は, 組織間で秘密保持の覚書を 結び，通常の連携では踏み込めない情報む互いに開 示している.

宇部興産は, 山口大学と包括的連携を締結する一 方で, 知的クラスター創成事業に対して形式上参加 している. 同社は医療機器を製造・開発していない ため, 同社の子会社で医療機器製造に携わる「ウべ 循研」が知的クラスター創成事業に関わっているの が実態である．宇部興産が参加した形態をとってい るのは, 地域に対する配慮と考えられる。C1 ケミ ストリーやリサイクル技術といった宇部興産が産学 連携で進めたい方向と，医工連携を核とした医療福 祉分野の製品開発という地域の方向とは，一致して おらずズレが生じている.

このほか, 産学官連携のコーディネーターに多く の宇部興産退職者が着任している点にも注目したい. 大学や自治体等の産学官連携支援機関には, 大学・ 企業間の連携を円滑に進めるため, コーディネータ
一が配置されている．宇部市で活動するコーディネ ーター 17 人のうち 12 人が宇部興産退職者であっ た35). 各機関は，コーディネーターに研究開発や 経営管理等に経験豊かな人材を起用したいため,こ の地域でそのような人材を求めると, 結果的に宇部 興産退職者が多くなったという36)。宇部興産は,

長年, 工場や研究所を宇部市に置いてきたため，そ のような人材が退職してあ市内に居住していること が多い. 宇部興産の拠点配置とそれに伴う人材の蓄 積が, 結果として産学官連携の推進に寄与している といえる.

2) 中小企業にとっての産学官連携

産学官連携の進展が進み中小企業に果たした影響 が比較的明らかな知的クラスター創成事業の参加企 業と, 連携構築が産業集積にとって意義深いと考え られる宇部鉄工業協同組合医療福祉部会の事例を取 り上げる.

(1)知的クラスター創成事業の参加企業

知的クラス夕一創成事業には, 地元中小企業屯参 加している. その参加企業は, 「LED に関する研究 開発の実績があった企業」あしくは「これまでにも 数度, 産学連携を経験し, 産学連携に意欲的であっ た企業」のいずれかであった。

前者は FD 社や ET 社のように宇部地域の知的ク ラスター創成事業のテーマと自社保有技術が密接な 企業である.このうち $\mathrm{FD}$ 社は, 電気工事業で蓄積 されてきた自動制御技術を生かして1990年代後半 にプラズマ溶射装置や LED 装置を製造・開発して きた。この事業を契機に, 山口大学工学部と共同で, 省エネ性能に優れた熱プラズマの溶射装置を開発し た経験を有する。これらの企業は, 事業のテーマと 自社保有技術が密接に関係しているため, 技術の深 化に力点が置かれている.

他方, 後者は医療機器や LED と関係のなかった 企業である.このうち, 金型・精密加工製造業を営 む AM 社は, 1997 年度に宇部高専と鏡面研磨砥石 
を開発して以来, 山口大学工学部, 山口東京理科大 学などと産学連携による製品開発を行ってきた．当 初は, 金属・精密加工分野での産学連携がもっぱら であったが,「うべ医療福祉産業研究会」への参加 によって, 異業種の企業だけではなく大学・病院関 係者との接触の機会を得ることができ，医療現場の ニーズを知ることができた，精密加工技術に長けて いた AM 社は, 2001 年に山口大学医学部消化器 • 腫瘍外科学と共同で手術用鉗子を開発し，その後屯 医療機器の開発を続けている. また, 住宅機器や半 導体製造装置メーカーである CS 社も, 1990 年頃 から, 海苔の湿度コントローラを下関市の水産大学 校と連携して開発して以降, 山口大学, 宇部高専, 山口東京理科大学などとの産学連携を行ってきた。

$\mathrm{CS}$ 社屯, 当初は工学部の研究者との産学連携がも っぱらで, 自社製品に関連した液晶・ディスプレイ 関連機器や高効率のインバー夕回路を用いた機器を 開発していたが，2000 年代以降，医療機器市場へ の参入を狙って医学部の研究者や医師との連携が増 え, 内視鏡の先端加工やステントの研究開発など屯 行っている.このように従来とは異なる市場への参 入を目的として産学連携に積極的な企業む存在する. 産学連携によって新たな製品を開発することで, 取引相手も徐々に拡大している. 医工連携を基盤と した産学連携が始まって期間が浅いため量的には少 ないが, 大学の研究者を通じて接触できた東京や大 阪等域外の医療機器卸業者のような従来とは異なる 企業との取引あみられるようになっている。一方, メディカル・クリエイティブ・センターの入居企業 間での研究開発の共同化 37$)$ 等, 経済的取引だけで はない関係も宇部市内で構築され始めている.

このほか，中小企業が産学連携に取り組んでいる 要因として費用的な要因あある。第 1 に, 研究開発 費を抑えて新しい技術を獲得できる，産学連携を進 める企業に対して，国や自治体からさまざまな補助 金・助成金制度が用意されているため, 企業は産学
連携に取り組みやすい，第 2 に，知的財産の登録・ 管理に伴う体制が大学に整備されているので, これ を利用することで費用的にメリットがある.

(2)宇部鉄工業協同組合医療福祉部会

宇部興産の下請企業の中にも, 産学連携をベース に新製品の開発に取り組む企業が現れている，宇部 鉄工業協同組合は，製缶・金属機械加工を行う中小 企業で組織され，そのほとんどの企業は宇部興産か ら受注の大半を受ける下請企業で構成されている. 同組合は, 戦前, 宇部地域の鉄工業者 11 社で結成 されていた同業組合を発展的に解消し，1955 年に 31 社で発足した。 高度経済成長期に参加企業が増 加し，1985 年時点で 37 社にまで拡大したが， 2005 年時点で 26 社に減少している。業種別に, 製缶, 仕上げ, 鋳鍛造の 3 部会に分かれ, それぞれの部会 で企業視察旅行や親睦会を開き，交流を図っている.

1990 年代後半以降, 宇部興産の機械・エンジニ アリング部門の不振により組合内で廃業・倒産が相 次いだため危機感が高まり, 2002 年度から国・県 の助成金を受けた新分野への挑戦を続けている. そ の取組みの一つが, 学術機関および異業種とのコラ ボレートによる医療機器の開発である. 切削加工技 術に実績のある企業 6 社が組合内に医療福祉部会を 設け,「パーキンンン病の定位的外科手術における 微小電極把持及び微動装置」の開発に着手した. 企 業 6 社は, 精密機械加工技術, 歯切・フライス加工 技術, 鍛造技術, 溶接技術 - 試作品の製品化, 金属 加工材質情報の提供・営業, ウハウ, 介護福祉機器 の販売という自社が保有する経営資源・技術をそれ ぞれ持ち寄って役割分担を行った。 パーキンソン病 治療機の製造によって, 医療機器市場に参入する足 掛かりを得ることができた。このような動きには, 医療ニーズと中小製造業者の保有技術とをマッチン グした医療業界に人脈を持つ地元企業や，助成金の 情報提供やその申請に伴う煩雑な手続きを支援した 商工会議所や市の支援が欠かせなかった。 


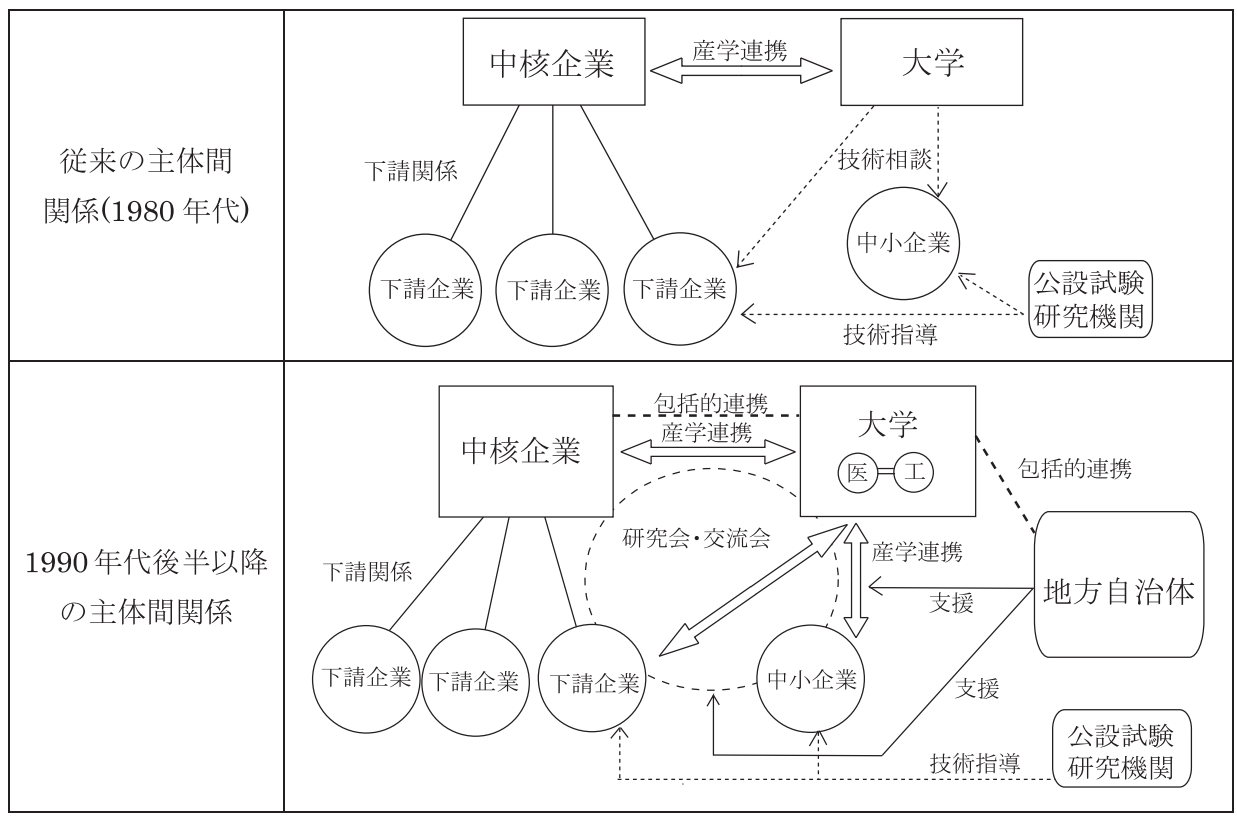

図 4 宇部市における主体間関係の変化

Fig. 4 Changes in actors' relations in Ube

ただし，この医療福祉部会の各企業の取引相手 · 取引金額が大幅に転換したといえるほどではなく, 従来の取引関係はほとんど維持されているのが現状 である，下請企業において，中核企業との下請関係 を基調としながらむ，さまざまな主体や異業種によ り構成される関係が新たに構築されつつあり，これ は脱下請の萌芽とみることができよう。

\section{4. 産学官連携の進展之産業集積の質的変化}

宇部市において，1990 年代以降の産学官連携の 進展に伴い, 主体間関係は変容した（図4)。従来 の主体間関係の中核は宇部興産であったが, 産学官 連携の進展により宇部興産に加えて, 技術協力や知 識の波及において重要な役割を果たす山口大学が主 体間関係の中核となっている. 山口大学と宇部興産 とは, 1980 年代から産学連携を行っていたが, 包 括的連携締結後, さらにその結びつきは強くなった. 産学官連携の進展により, 産業集積に变化が生じ た. 従来, 中小企業が技術を獲得するためには独力
で獲得するか公設試の助力を得るしか方法がなかっ たが，産学官連携により技術を獲得するとともに， 取引相手や共同研究相手を獲得できるようになった. 産学官連携の過程の中で，これまで関係のなかった 企業間で共同研究を行うような集積内の企業間関係 の再構築も始まる一方で, 域外の企業との取引関係 あ徐々に構築されつつある.

特に宇部興産の下請企業にとって, 産学官連携の 進展は今後, 脱下請の手段になり得ると考えられる. 中小企業単独では資金・人材・技術的に困難な新事 業への進出む，新たな関係を構築することによって， 親企業以外から技術を獲得できるとともに，コーデ ィネーターや交流会等を通じて親企業以外の新たな 取引相手・共同研究相手を見つけることができ, 脱 下請化を促進できる。つまり, 宇部市における産学 官連携は, 従来の宇部興産とその下請企業から構成 される垂直的な構造から, 域内・域外の企業や大学, 公設試等と, 取引や共同研究の関係を構築する水平 的な構造に転換させる役割がある。 また，それは産 
業集積のロックインを解放する取組みとして重要な 意味を持っているといえる.

このような連携の進展は, 以下の地域的コンテク ストの上に成り立っている. まず, 学術・研究機関 の存在とその関係が挙げられる。宇部市は, その都 市形成の中で学術・研究機関を複数有してきたが, これは地方都市の中では稀れである。これら学術・ 研究機関は単に存在していたのではなく, 地域の他 の主体との関係を構築してきた. 特に山口大学の組 織の中で, 医学部と工学部だけが宇部市にあり近接 していたことが，現在の医工連携進展の促進に影響 していると考えられる。 また, 中核企業の性格む, 域外資本が進出した他の企業城下町と異なる。宇部 興産は, 地元で形成された企業である38）ため, 地 元を重視する「共存同栄」の企業精神が現在であ継 承され, 産学官連携においても地元の大学を重視し ている. また, 宇部興産は主力の生産・研究開発拠 点を市内にとどめていたため, そのような人材が蓄 積し、コーディネーターとして連携の進展に寄与し ている.

\section{IV 結 論}

これまでの議論をまとめ考察を加える.

宇部市は, 明治期以降, 石炭産業の隆盛とともに 発展を遂げ, 石炭産業の衰退以後, 化学工業が地域 産業の牽引役となってきた。中核企業の宇部興産は, 石炭産業とそれで蓄積された資金を基に設立された 企業とを統合して設立され，宇部で形成された企業 である，宇部興産は, 高度経済成長期以降, 生産拠 点の拡散や本社機能の東京移転によって「宇部から の離陸」を進めてきたが, 宇部市は, 同社にとって 現在でも重要な生産・研究開発拠点である. 宇部市 では，宇部興産を核に中小企業がその下請仕事に従 事するという企業間関係が構築されてきたが, 下請 企業はこの関係に長期間に渡り安住してきたため, 情報獲得力や営業力の欠如等の問題を抱えている.
そのような問題は，中核企業の業績が悪化した時に 顕在化する. 特に 1990 年代に, 宇部興産の業績悪 化に伴いリストラクチャリングが相次いで実施され, 大企業，中小企業ともに厳しい状況に陥ったため, 地域全体で危機感が形成されていった。一方，第 1 に 1940 年前後に, 宇部市に現在の山口大学の前身 となる学校が設立されたこと, 第 2 に 1950 年代に 産学官が連携して公害対策に取り組んだこと, 第 3 に 1980 年代にテクノポリスに指定され, 学術・研 究機関の充実化が図られるとと屯に，大学と地元企 業との交流が始まったことが，今日の産学官連携の 基盤となっている.

1990 年代以降の産学官連携の進展により, 従来 の宇部興産に加えて, 山口大学が主体間関係の中核 になっている. 国立大学の法人化に伴う新たな研究 資金の確保を目的とする大学や，財政状況の改善之 産業構造の転換を目的とする自治体は, 産学官連携 支援システムを整備した。宇部興産は，大学との連 携強化によって, 製品開発の高付加価值化を進めて いる.ただし，宇部興産が産学官連携で進めたい方 向と，医工連携を核とした地域の方向とは，ズレが 生じている. 一方, 中小企業は産学官連携の進展に より技術や取引相手・共同研究相手を獲得すること で, 従来の企業間関係を維持しながら取引相手を拡 大させている，特に宇部興産の下請企業にとって産 学官連携は, 脱下請化を促す可能性がある.このよ うに宇部市における産学官連携は, 従来の宇部興産 とその下請企業から構成される垂直的な構造から, 域内・域外の企業や大学, 公設試等と, 取引や共同 研究の関係を構築する水平的な構造に転換させる役 割があるとともに，それは，産業集積のロックイン を解放する取組みとして重要な意味を持っていると いえる.

このような宇部市の産学官連携は, 地域特有の状 況を反映して進展してきた。地域的コンテクストと $し て$, 学術・研究機関の存在とその関係, 地元を重 
視する中核企業の企業精神とその人材蓄積がある.

最後に, 地域産業にとっての産学官連携, 特に大 学の果たす役割について考える. 宇部市では, 産学 官連携の進展により, 宇部興産に加えて山口大学が 主体間関係の中核に位置づけられるようになってき たと述べた。しかし, 山口大学が宇部興産にとって 代わるほどの存在になるとは言い難いであろう。大 学は今後む企業に知識や学習の場を提供する役割を 強めていくであろうが, 大学の性格上, おのずから 限界がある。予察的に述べると, 産学官連携が進展 した企業城下町では, 今後, 大学は中核企業と補完 的な役割を果たしていくのではなかろうか.この点 については, 今後の研究課題としたい.

本研究を進めるにあたり, 聞取り調查に御協力下さっ た方々に厚く抢礼申し上げます。また，論文作成にあた り御指導いただきました東京大学の松原宏先生をはじ めとする諸先生方・院生諸氏に深く感謝いたします。な お本稿は, 2006 年, 東京大学に提出した修士論文を加 筆・修正したものであり，その骨子は，2006 年度日本 地理学会春季学術大会, 経済地理学会関東支部例会 （2006 年 4 月）で発表した.

(投稿 2007 年 8 月 3 日) (受理 2008 年 10 月 11 日)

注

1）産業技術力強化法施行により，大学㧍よび大学の研究 者に対する特許料等の軽減, 民間企業の役員兼業規約の 緩和，資金助成等が可能になった。

2） 1964 年に奨学寄附金制度，1970 年に受託研究制度， 1983 年に共同研究制度がつくられ，また，1980 年代後 半から, 全国の国立大学に産学連携のリエゾンオフィス としての共同研究センターが設置されるなど, 産学連携 に関する制度・施設は以前から存在していたが, 産学連 携が積極的に取り組まれたのは, 1990 年代以降である。

3）経済産業省は, 産学官ネットワーク形成や新産業・新 事業の創出支援を図るために, 2001 年から「産業クラ スター計画」を実施している。 この計画は, 基本的に各 地方の経済産業局単位で計画され，第 1 期（2001 2005 年度)に19のプロジェクト, 第 2 期（2006〜2010 年 度）に 17 のプロジェクトが進められている.

4）文部科学省は，大学を核とした技術革新型のクラス夕 一形成を目指して，2001 年から「知的クラスタ一創成
事業」を実施している．全 18 地域が事業実施地域とし て指定されている.

5）本稿では, 断りのない限り, 宇部市に関する国勢調 查・工業統計表・事業所統計は, 2004 年 11 月に楠町と の合併以前の市域のものを用いた.

6) 宇部興産は, 従業者数 3,361 人 (単独), 11,074 人 (連結), 資本金 485 億円, 2004 年度の売上高 2491 億円 (単独), 5627 億円（連結）の東証 1 部上場（化学）の 企業である (2005 年 3 月現在).

7）宇部市の工業全体に占める宇部興産の割合は, 従業者 数で $22 \%$, 製造品出荷額等で $40 \%$ である. 宇部市の工 業全体は 2004 年 12 月実施の工業統計表, 宇部興産 （2005 年 3 月現在）は聞取り調査による.

8) 山口大学は宇部市に工学部之医学部, 山口市に人文学 部, 教育学部, 理学部, 農学部がある国立大学法人であ る. 2005 年 5 月現在, 工学部之医学部 (付属病院含む) に 1,144 名の教員が在籍している.

9）本稿では, 産学連携が活発な山口大学を中心に取り上 げる。宇部高専に扔ける産学連携の状況は, 木村 （2004）を参照されたい.

10）詳細は，本稿の III の 1の 1）を参照.

11)「宇部」とは, 現在の宇部市に相当する範囲である.

12）当時, 渡邊は「天与の資源である石炭は, やがて掘 り尽くす時が来るが, 宇部の地域社会がこれと運命を共 にしないよう永続性のある工業を興しておかなければな らない」と考えていたとされる（宇部興産株式会社 1998).

13） 1950 年における宇部興産の石炭部門の売上高は, 全 部門のうち 4 割を占めていた（宇部興産株式会社 1998）。

14）宇部興産宇部地区は, 宇部市のほかに周辺市町村の 同社の事業所も含んでいるが, 大半は宇部市内に立地し ている.

15）戦後, 山口県立医学専門学校は大学に昇格し, 山口 県立医科大学々なった。

16）宇部短期大学は，2002 年， 4 年制の「宇部フロンテ ィア大学」に改組した.

17） 1990 年, 超高温材料研究センターは, 新エネルギ -・産業技術総合開発機構 (NEDO), 山口県, 岐阜県, 宇部市，多治見市および企業 45 社による第 3 セクター 方式の共同出資により設立され，2005 年に超高温材料 研究所へ事業が継承された。 山口事業所, 岐阜事業所の 2 力所がある.

18）宇部テクノポリスの目標達成状況をみると, 目標年 次 1995 年度時点において, 工業出荷額が目標值の 78.6 $\%$, 工業付加価值額が $72.9 \%$, 工業従業者数が $100.8 \%$ であり, 目標年次 2000 年度時点において, 工業出荷額 が $91.4 \%$, 工業付加価值額が $76.5 \%$, 工業従業者数が 89. $9 \%$ であった (宇部市資料による). 
19）研究協力会の参加企業のうち, 企業情報を得ること ができた 97 社すべてが山口県内に事業所（本社, 支店, 工場等）を置く企業であり, 中小企業 53 社, 大企業 44 社であった。 これらのうち, 宇部市内に事業所のある企 業は 45 社であった。

20） 1996～2005 年度累計の共同研究数において，山口大 学は, 東京大, 大阪大, 東北大, 京都大, 東京工業大, 九州大, 名古屋大, 北海道大, 東京農工大に続いて全国 の国立大学の中で 10 番目に共同研究数が多い.

21）文部科学省（2005）によると，2004 年度における山 口大学の共同研究の研究費が総額 2 億 8143 万円, 受託 研究の研究費が総額 6 億 7256 万円で, 共同研究相手先 機関別の 1 件当たりの平均研究費が 130 万円, 受託研究 相手先機関別の 1 件当たりの平均研究費が 756 万円であ る. 全国の国立大学の平均值は, 共同研究相手先機関別 の 1 件当たりの平均研究費が 233 万円, 受託研究相手先 機関別の 1 件当たりの平均研究費が 986 万円であり, 山 口大学は共同研究数が多いものの, 1 件当たりの金額は 全国に比べて低い.これは, 山口大学が中小企業との共 同研究が多いことが影響しているためと考えられる.

22）この表彰は, 当たり前のように思っていた大学の存 在を，市当局が再評価する契機になった（宇部市に対す る聞取り調査による).

23）同研究会には, 各分野に関心のある企業や大学の研 究者が参加し, 新技術の勉強会や講演会を定期的に開催 している.

24）「やまぐち産業振興財団」は，「山口県産業技術開発 機構」と「山口県中小企業振興公社」が 2000 年に統合 して設立された. 中小企業の経営相談や販路開拓, 設備 購入資金の貸付といった従来型の中小企業支援のほか, 産学官の技術交流促進や起業支援等も行っている.

25）特に 1990 年代後半, 法人市民税の落込みが激しく, 1999 年の宇部市予算案では, 法人市民税は前年に比べ て $32.2 \%$ 減少した（日本経済新聞 1999 年 2 月 20 日付 による).

26）基礎素材型産業は，木材・木製品，パルプ・紙・紙 加工品, 化学工業, 石油・ゴム・石炭, プラスチック製 品, 窯業・土石製品, 鉄鋼業, 非鉄金属, 金属製品を, 加工組立型産業は, 一般機械器具, 電気機械器具, 輸送 用機械器具, 精密機械器具を, 生活関連型産業は, 食料 品, 飲料・飼料・たばこ, 繊維工業, 衣料・繊維製品, 家具・装備品, 出版 - 印刷 $\cdot$ 同関連, 皮革製品, その他 製造業を指す。

27）このサロンは宇部市長の発案によって設立された. 1990 年代前半まで, 宇部市において異業種間や産学官 の交流はさまざまなかたちで行われてきたが, 地域全体 に波及しなかった。 そこで宇部市長は, 産学連携に関わ る経営者や研究者・行政関係者が交流できる場をつくる
ことを発案した．ただし，市役所や商工会議所の主催で は堅苦しく長続きしにくいことが想定されたため，民間 企業が主導し市が後援する形態にした．宇部市長は，宇 部市内で産学連携に理解・実績のある企業に対して, サ ロンの取りまとめ役である幹事会社となるように依頼し, サロンの設立を実現した。

28）「キューブサロン設立趣意書」（2003 年 8 月策定）に よる.

29） RSP 事業では, 地域ニーズ・研究シーズと研究情報 の整備状況の調査, 研究成果の実用化可能性試験, 地域 におけるコーディネート機能の構築が行われる. RSP 事業は都道府県単位で行われ, 山口県では, やまぐち産 業振興財団を拠点機関として実施された.

30）入居の条件として, 医療・福祉分野の研究開発を行 う企業に限った.

31）知的クラスター創成事業における「宇部地域」は, 明確な空間的範囲を定められていない。

32）知的クラスター創成事業が本格実施された事業実施 地域では 5 年間, 各年 5 億円が文部科学省から提供され るが, 試行地域では $1 \sim 3$ 年間, 各年 3 億円が提供され る.

33）補助金の実施主体（審査・授与）は財団が行うが, 財源は山口県の単独事業である. 知的クラスター創成事 業の研究開発に関わる試作機製作等に要する経費の一部 が補助される.

34）DR 社はそれぞれ LED 開発・製造・販売部門を分社 化して設立された.

35）機関によって役職名が異なるため, 本稿では中国地 域産学官コラボレーションセンター（2004）に拈いて紹 介されている人物をコーディネーターとした.

36）宇部興産に対する聞取り調査によると，退職者に対 するコーディネーターの斡旋は行っていない.

37） $\mathrm{AM}$ 社と LG 社は, 両社ともメディカル・クリエイ ティブ・センターに入居しており, 病態特異的 DNA の 解析に基づくがん悪性度診断システムを共同で開発した。

38）和田（1966）は, 中核企業が地元資本によって形成 された宇部市を「民族資本型」の企業城下町と位置づけ, 域外資本が進出した「植民地型」と対置させている.

\section{文 献}

石倉洋子 - 藤田昌久 - 前田 昇 - 金井一頼 - 山崎 朗 2003.『日本の産業クラスター戦略——地域における競 争優位の確立』有斐閣.

伊藤正昭 2003. 地域における企業間関係——企業城下町 型集積の内部構造. 伊藤正昭『新版 地域産業論—産 業の地域化を求めて』143-189. 学文社.

岩間英夫 1991. 宇部鉱工業地域社会の形成と再生の要因. 人文地理 43: 181-192. 
岩間英夫 1992. 宇部と日立の比較からみた鉱工業地域社 会の内部構造とその発達過程. 地理学評論 65A：635652.

岩間英夫 1993.『産業地域社会の形成・再生論一日立鉱 工業地域社会を中心として』古今書院.

宇部興産株式会社 1998.『宇部興産創業百年史』宇部興産 株式会社.

宇部市史編纂委員会編 1966.『宇部市史 通史編』宇部市 史編纂委員会.

宇部市史編集委員会編 1993.『宇部市史 通史編 下巻』宇 部市史編集委員会.

宇部商工会議所 1996. 『21 世紀へ翔くテクノ・フロンテ ィア宇部 宇部市工業振興ビジョン』宇部商工会議所.

太田 勝 1998. 宇部の歴史的発展と変容. 宇部工業高等 専門学校研究報告 44: 77-96.

太田 勝 1999. 宇部における基盤産業の発展と産業構造 の変化一一炭都から鉱工業都市へ，宇部地方史研究 27 : $1-24$.

岡本信司 2007. 地域クラスターの形成と発展に関する課 題之考察——浜松地域と神戸地域に招ける比較分析. 研 究 技術 計画 22：129-145.

加藤秀雄 2003. 『地域中小企業之産業集積』新評論.

鎌倉 健 2002.『産業集積の地域経済論一一小企業ネッ トワークと都市再生』勁草書房.

北田晃司 1991. 宇部市における工業の質的転換と地域の 発展との関係. エリア山口 20：45-51.

木村 弘 2004. 中小企業における産学連携の意義—宇 部高専における中小企業との産学連携。九州経済学会年 報 42：87-93

末吉健治・松橋公治 2005. 産業支援システムの形成と企 業間ネットワークの展開一山形県米沢市における産業 支援システムを中心に．福島大学地域創造 16(2)：3765 .

関 満博・岡本博公編 2001.『挑戦する企業城下町一一造 船の岡山県玉野』新評論。

武田尚子 2000. 村落から工業都市への变容——宇部にお ける企業経営者層の形成. 年報社会学論集 13：215-226. 田中康一 2002. 企業本社機能立地と都市機能との関係に 関する一考察——が国製造業大企業 100 社に関する実 証的分析より (3). 高知論叢 73: 17-45.

田中史人 2004.『地域企業論——地域産業ネットワークと 地域発ベンチャーの創造』同文舘出版。

中央大学経済研究所編 1976.『中小企業の階層構造一日 立製作所下請企業構造の実態分析』中央大学出版部. 中国産業活性化センター 2001。『山口県宇部周辺地域振興 計画調査報告書——宇部地域の医工連携システムの構築 方策調査』中国産業活性化センター.

中国地域産学官コラボレーションセンター 2004.『中国地
域新産業・産学官連携コーディネーター等一覧』中国地 域産学官コラボレーションセンター。

堂野智史 2004. 産学連携基盤としての産学官民コミュニ ティの形成—INS，KNS の事例を通じて，産業学会 研究年報 20：31-42.

遠山恭司 2002.「企業城下町・日立地域」における中小企 業の自立化と地域工業集積. 中央大学経済研究所年報 33: 121-144

友澤和夫 2000. 生産システムから学習システムへ— 1990 年代の欧米における工業地理学の研究動向. 経済 地理学年報 46：323-336.

日本政策投資銀行中国支店 2002. ニ ズ重視の実践的産 学連携一山口大学医学部・工学部と企業の連携システ ム. かたりすと 12：10-11.

林 正巳 1968. 宇部市における都市機能の変容——自治 機能を中心として．政治地理 3：313-330.

藤田和史 2007.「知識・学習」からみた試作開発型中小企 業の発展とその地域的基盤一一長野県諏訪地域を事例と して. 地理学評論 80：1-19.

ポーター, M. 著, 土岐 坤・中辻萬治・小野寺武夫・戸 成富美子訳 1992.『国の競争優位 上・下』ダイモンド 社. Porter, M. 1990. The competitive advantage of nations. New York: Free Press.

ポーター, M. 著, 竹内弘高訳 1999。『競争戦略論 I ·

II』ダイヤモンド社. Porter, M. 1998. On competition. Boston: Harvard Business School Press.

松野浩二 2005. 産業都市宇部に生まれた工学と医学．松 野浩二『奮発震動の象あり』271-282. 財団法人鳳陽会 松橋公治 2004. 中小企業集積地域に打ける企業外環境ネ ットワークの地域間比較——花巻・北上両市における産 業支援システムを中心に．明治大学人文科学研究所紀要 54：229-269.

松原 宏 1999. 集積論の系譜と「新産業集積」. 東京大学 人文地理学研究 13: 83-110.

三浦典子 2004. 企業文化の形成と企業の社会貢献活動 一一企業城下町宇部市の変容. 三浦典子『企業の社会貢 献とコミュニティ』198-218. ミネルヴァ書房.

三木俊克 2003.「山口大学における医工連携及び産学連 携」の歩みと今後. 知的クラスターセンターNEWS 医 工連携特集号：13-20.

宮町良広 2003. 英米の産業集積と地域に扔ける学習・イ ノベーション．大分大学経済学部編『グローバル化と日 本の経済・社会』227-245. ミネルヴァ書房.

森 真澄 1977. 日本の企業経営と地域社会一一地方工 業都市 (宇部) の事例研究. 中川敬一郎編『日本経営史 講座 5 日本的経営』252-282. 日本経済新聞社 師井於菟彦 1967。一地方工業都市に扮ける公害問題— 宇部市の大気污染対策の事例. 地理科学 8：10-19. 
文部科学省 2005 . 平成 16 年度 大学等における産学連携 等実施状況報告書. http://www.mext.go.jp/b_menu/ houdou/17/06/05062201/001.htm（最終閲覧日：2007 年 7 月 1 日)

文部科学省科学技術政策研究所 2003. 産学連携 19832001. 調査資料 96 .

山川充夫 1995. 地方における連携型産業集積. 下平尾 勲編『共生と連携の地域創造一一企業は地域で何ができ るか』29-67. 八朔社.

山口大学 2005. 平成 16 年度決算報告書. http://ds.cc. yamaguchi-u. ac. jp / syukei / 11 zaimushohyou / 16kessan.pdf（最終閲覧日：2007 年 7 月 1 日）

山口大学・宇部興産株式会社 2006. 国立大学法人山口大 学・宇部興産株式会社による「包括的連携協力」の推進 状況について (中間報告). http://www.yamaguchi-u. ac.jp/inform/press/2006/060405/（最終閲覧日：2007 年 7 月 1 日)

山口大学工学部 1990. 『山口大学工学部 50 年』東洋図書 出版.

山本健兒 2005.『産業集積の経済地理学』法政大学出版局.
和田八束 1966. 企業都市の性格と地域経済．都市問題研 究 18(6)：28-40.

渡辺幸男 1979. 大都市における機械工業零細経営の機能 と存立基盤一一東京都城南地域の場合. 三田学会雑誌 72: 179-211.

渡辺幸男 1990。 日本機械工業の社会的分業構造 (下) ——請制研究の新たな視点を求めて。三田学会雑誌 82: 819-841.

Camagni, R. 1991. Local 'milieu', uncertainty and innovation networks: Towards a new dynamic theory of economic space. In Innovation networks : Spatial perspectives, ed. R. Camagni, 121-144. London and New York: Belhaven Press.

Grabher, G. 1993. The weakness of strong ties: The lock-in of regional development in Ruhr area. In The embedded firm: On the socioeconomics of industrial networks, ed. G. Grabher, 255-277. London: Routledge.

Florida, R. 1995. Toward the learning region. Futures 27: 527-536. 


\title{
Industry-University-Government Collaboration and Transformation of Actors' Relations in a Company Town: Case Study of Ube City, Yamaguchi Prefecture
}

\author{
SOTOHEBO Daisuke (Graduate student, The University of Tokyo)
}

The purpose of this study is to discuss the role that industry-university-government collaboration plays in industrial agglomeration by investigating the realities of such collaboration and transformation of actors' relations in a company town. This is a case study of the city of Ube, the company town of Ube Industries.

Traditionally, the core of actors' relations in Ube was Ube Industries. Many SMEs are subcontractors of Ube Industries. Relations between Yamaguchi University and actors were built gradually. Industry-university-government collaboration overcame air pollution in the $1950 \mathrm{~s}$. In the 1980s, Ube and its neighboring region were selected to become a technopolis. At that time, the basis for industry-university-government collaboration was solidified. In addition to attracting the university and a laboratory, exchanges between local enterprises and Yamaguchi University started.

With the progress of industry-university-government collaboration, Yamaguchi University and Ube Industries became the core of actors' relations in Ube. The university interacts with large enterprises that have local connections and local governments in a form of inclusive cooperation. Ube Industries uses the collaboration for the high value-added product development. SMEs acquire new seeds and have increased the number of customers. Subcontractors are supported in being independent. Such collaboration can unlock locked-in industrial agglomeration.

Key words: company town, industry-university-government collaboration, actors' relations, city of Ube 